\title{
Thai undergraduate science, technology, engineering, arts, and math (STEAM) creative thinking and innovation skill development: a conceptual model using a digital virtual classroom learning environment
}

\section{Naphong Wannapiroon ${ }^{1}\left[\right.$ D Paitoon Pimdee ${ }^{1}$ (D)}

Received: 7 June 2021 / Accepted: 2 December 2021/ Published online: 16 January 2022

(c) The Author(s), under exclusive licence to Springer Science+Business Media, LLC, part of Springer Nature 2021

\begin{abstract}
Qualitative and quantitative research methods were undertaken to examine and develop a digitally based virtual classroom learning environment (VCLE) for Thai undergraduate students' creative thinking and innovation enhancement in science, technology, engineering, arts, and math (STEM/STEAM) disciplines. The research methodology was divided into two phases, including the synthesis and then the design of the VCLE. Also, in addition to the study's authors, nine experts were used for the model's development and another ten for its assessment (19 total). From their in-depth interviews and subsequent content analysis, their input of the proposed STEAM-ification process was synthesized and the data analyzed. The results revealed that the VCLE design should begin with a face-to-face, classroom learning environment in which the 'gamification' mechanisms were introduced and examined. This was then reinforced by moving the gamification process online outside of the classroom. Furthermore, five VCLE STEAM-ification steps were found to be particularly useful for enhancing creative thinking and student innovation. These included investigation, discovery, connections, creativity, and reflection. Moreover, we identified the gamification process as consisting of three main components. These were the 'game mechanics,' the 'game dynamics', and 'player emotions'. The ten experts agreed that the VCLE STEAM-ification creativity and innovation (C \& I) process was appropriate at an 'excellent' level $(\bar{x}=4.68$, S. D. $=0.47)$, which has great potential in the development of Thai undergraduate student C \& I skills. Also, when undertaken correctly, innovation and motivation to learn are also outcomes from both VCLE and gamification applications. Thus, when students undertook study with the VCLE STEAM-ification format, they were found to achieve higher levels of creativity and innovation than students who studied using the traditional teaching plan. These results were found to be statistically significant at the .01 level.
\end{abstract}

Extended author information available on the last page of the article 
Keywords $21^{\text {st }}$ Century education $\cdot$ Creative Thinking $\cdot$ Critical thinking - Digital Learning Environment · Gamification · Innovation skills · STEAM-ification · STEM - Thailand

\section{Introduction}

Education in the 21st Century has become more reliant on information and communication technology (ICT) (Alismail, 2015). Numerous new learning models have evolved, such as the flipped classroom and blended learning (Banyen et al., 2016; DeLozier \& Rhodes, 2017; Ekici, 2021; Wannapiroon \& Petsangsri, 2020). These new environments allow students to choose when and how they are learning content, and when they come to class, they can free the instructor for problem-solving exercises or content questions and answers (Eppard \& Rochdi, 2017; Shih \& Tsai, 2017). Therefore, the teacher's role has evolved as well within these new digitally-enabled environments to that of a 'knowledge facilitator' (KF), in which each KF (teacher) arranges the appropriate circumstance for learning (Phuapan et al., 2016).

Also, Boholano (2017) has injected that 21st Century generation Z students expect and use ICT and social media like fish do to water. The author also points out how pre-service teachers and their respective institutions should be technically savvy and properly outfitted if they expect to engage this newer generation of students effectively. Moreover, students should have freedom of thinking capabilities created from the cognitive, affective, emotional, and psychomotor domains (CAP domains) (Chaffar \& Frasson, 2012; Illeris, 2002). Also, Darling-Hammond et al. (2020) added that learner development of higher-order thinking skills (HOTS) could best be achieved through inquiry and investigation, knowledge application to new problems and situations, idea and solution production, and collaborative problemsolving. This is consistent with Laisema and Wannapiroon (2014), who also added the importance of problem-solving techniques, searching for new information, and having good morality and responsibility, critical thinking, creative thinking, and productivity. Furthermore, UNICEF has also reported that there are 12 core life skills. Of these, creativity is listed first, and critical thinking is second. Also, both are stated to be core life skills in which educators should begin developing in students at an early age (Carlile \& Jordan, 2012; Dilley et al., 2015).

In Thailand, Techakosit and Wannapiroon (2015) designed research in which they used a connectivism learning environment to connect augmented reality (AR) with science laboratory students to increase their scientific literacy. Once again, science literacy development is seen as a process in which the students are tasked to understand and solve problems while searching for the necessary information to solve the problem. After that, reasoning is required to assess what has been discovered, at which point reflection is necessary to present what has been found. Also, in Thailand, Sarnok et al. (2019) explored a model or ecosystem for digital storytelling, which the authors concluded made use of a variety of digital media, including still images, short films, animations, audio, video games, applications, or content designed on a cloud-based website. This is consistent with another STEAM study from the US state of Pennsylvania in which girls were encouraged to use technology 
to explore and create various types of digital art-making through activities involving storytelling, personal experiences, and technology literacy by making video games, animations, and machinimas (Liao et al., 2016).

Virtual classrooms are also learning methods that facilitate learners gaining twenty-first century skills in the 'Four Cs' which once again includes creative and critical thinking skills, communication skills, and collaboration (Liao et al., 2016; Riegel \& Kozen, 2016), which also enhances twenty-first-century in learning and innovation for higher education learners (Songkram, 2017). Moreover, Songkram (2017) suggests that the learning process consists of four steps: material introduction, student learning, creation and innovation, and finally, the evaluation phase.

Also, numerous studies have been undertaken to find which digital education methods are most effective in student STEAM development skills. One example is Ortiz et al. (2016), which conducted a literature review of how gamification in STEM subjects affected higher education (HE) students. From the results the authors determined that game element combinations (e.g., leaderboards, badges, points, etc.) positively affect a student's attendance, goals, attitude, and performance towards computer science-related subjects. In Canada, Bertrand and Namukasa (2020) evaluated multiple STEAM curriculums and reported that each was involved in critical thinking and problem solving, collaboration and communication, and finally, creativity and innovation, which can be transferred to other disciplines (Liao et al., 2016). Furthermore, it was noted from the Canadian programs that each had an initial stage that built on a student's curiosity and interest in the material presented.

In summary, from this overview, we propose a more in-depth literature review concerning the STEAM-ification of a digitally based virtual classroom learning environment (VCLE) for Thai undergraduate students' creative thinking and innovation enhancement. We intend to focus on how gamification features can be applied in STEAM education and the available methods in the virtual classroom..

\subsection{Research problem}

Globally, numerous studies have addressed what has been called 'core values' of a $21^{\text {st }}$ Century citizenry and workforce; critical thinking and creativity skills. Moreover, the crucial nature of science, technology, engineering, arts, and math (STEM/ STEAM) disciplines has risen from a faint whisper to a loud roar. Therefore, educators and institutions have sought out new ways to develop these skills in their student curriculums. Methods are numerous, but most agree that information and communication technology (ICT) using the Internet as a transmission medium is a good foundation from which to start. When added to a growing plethora of software and media-based systems and environments, discerning which process, processes, or combination is difficult to ascertain for most educators and institutional administrators. This study, therefore, set out to identify through multiple panels of experts which factors have the potential to have the most significant positive impact on STEAM education, critical and creative thinking, and innovation using a digitallyenabled VCLE. 


\subsection{Research objectives}

1. From the qualitative research, we intend to synthesize the literature and determine which factors can play the most significant role in STEAM education in a digitally-enabled VCLE.

2. From the factors selected, we then examine each in combination with two panels of experts to develop a STEAM-ification model for Thai undergraduate students' creative thinking skills, their critical thinking skills, and their ability to innovate thinking (Wannapiroon \& Petsangsri, 2020).

3. Develop a framework to assess the model's appropriateness using the VCLE.

4. Finally, we will develop and efficiently evaluate the VCLE STEAM-ification use.

\section{Review of the literature}

\subsection{Virtual classroom learning environment (VCLE)}

The concept for a VCLE today lies in the combination of a virtual classroom (VC) and a digital learning environment (DLE) which allow teachers to connect with their students outside the classroom through a variety of online platforms using social media such as Facebook, Line, and WhatsApp (Moto et al., 2018), to cloud-based learning management systems (LMSs) such as Moodle or Schoology (Banyen et al., 2016). Also, VCs are now using interactive video conferencing tools such as Zoom, especially since the beginning of the Covid-19 pandemic and the shutdown of physical school campuses worldwide (Joia \& Lorenzo, 2021). Moreover, VCs are highly customizable and accessible to users through various digital devices, including smartphones, tablets, and laptops. However, Internet access and bandwidth constraints are frequently mentioned limitations to a VC's implementation and use.

Furthermore, undergraduate education is being transformed from digital technology integration in the classroom (Kadambaevna et al., 2021), where the importance of each teacher's learning activities is of essential importance in assisting students in building their comprehension and learning stimulation. Moreover, Thailand's ICT use in education has been prioritized under Thailand's 12th National Economic and Social Development Plan (Baxter, 2017) and precepts outlined under Thailand's 4.0 visions for a $21^{\text {st }}$ Century, critical thinking, and digitally-enabled workforce.

\subsection{STEAM education}

According to English (2017), STEAM education is a teaching method that focuses on heightening each student's interest in each discipline by increasing their expression, innovation, and aesthetic perception capabilities (Taylor, 2016), of which innovation is the most important (Hsiao \& Su, 2021). In the United States, STEM became a national priority imitated by the National Science Foundation for all levels of secondary education (Sanders, 2009), whose goal was to provide students with 
critical thinking skills that had the potential to make students creative thinking problem solvers who would eventually be marketable in the workforce (White, 2014). Today, an 'A' for arts has been added, and STEAM education is now helping students to comprehend their world better through diversity in knowledge and perspectives, which is conducive to their innovation capability cultivation (Connor et al., 2015; Miller \& Knezek, 2013). Finally, Ogunleye (2018) has stated that the key to STEAM education is the word, 'integration.'

Moreover, the addition of art to STEM is reinforced due to follow-on studies indicating the importance of art in helping learners develop their capability for innovation as various forms of technologies and mediums are used (Catchen, 2013; Conradty \& Bogner, 2018; Liao et al., 2016; Yuktirat et al., 2018). Bazler and Sickle (2017) have also commented that adding art to STEM increases student systematic thinking skills, creativity development, and student motivation enhancement. Furthermore, it is widely recognized that art stimulates cognitive skills such as problem-solving, critical thinking, listening, and decision-making in addition to other areas such as observational skills, listening skills, collaboration, and communications (Lynch, 2019; Thuneberg et al., 2018). Catchen (2013) has also added that in STEAM education, creativity is vital, and students can learn things about themselves they did not know before.

STEAM education also enables 'learning by doing' collaboration at solving real problems with actual processes. This allows students to connect their knowledge with their real-life (Patterson \& Muna, 2019). In Thailand, Chujitarom and Piriyasurawong (2018) examined gamification's use in STEAM education and reported that games are becoming more critical in Thai education. Moreover, gamification is a process that allows students to participate in learning. It also helps inspire and promote learning, solve problems, and drive behavior and is easily accessible through social media or web-based platforms.

Moreover, Conradty and Bogner (2018) have stated that creativity as a construct is broad and complex and challenging to define and quantify. Fortunately, after an analysis of 2,713 European students, the authors reported that STEAM might help develop critical thinking, solve real-world problems (investigation), help make learning science easier, and finally, support a student's motivation. However, Sosa (2011) has added that social distancing can inhibit creativity.

How and Hung (2019) have also investigated STEAM in the context of artificial intelligence (AI) learning and suggested that this process could enhance learning by challenging humans to interpret new findings from the machine-learned discovery (investigation) of hidden patterns in the data. The authors also felt that an underlying foundation in Industry 4.0 was AI principles and their integration through STEAM education. In Indonesia, Rahmawati et al. (2019) also reported that a STEAM approach helps develop chemistry students' problem-solving skills, critical thinking skills, and collaboration (connection). Interestingly, Perignat and Katz-Buonincontro (2019) have added that creativity is rarely assessed or measured as part of STEAM education and that there is great confusion about how art pedagogies are integrated into STEAM. This is also consistent with Baharin et al. (2018), who lamented that STEM integration could be challenging due to the requirements for educators with skills in STEM fields. 
Therefore, we summarized the STEAM learning process of our model using a VCLE as consisting of five elements, including the student's ability to investigate, their discovery process, how they collaborate or connect with others, how they create, and finally, how they reflect on what they have learned.

\subsection{Gamification}

According to Smiderle et al. (2020), gamification education can enhance student levels of engagement, improve specific skills, and optimize their learning. However, students' personality traits and characteristics can directly affect gamification lessons' effectiveness (Jia et al., 2016; Sanchez et al., 2019). Other studies have also stated that gamification can be a tool for optimizing learning, behavioral change reinforcement, and a socialization mechanism (Krause et al., 2015; Dichev \& Dicheva, 2017).

Specifically, gamification student stimulation is accomplished most often through a process referred to as 'game mechanics' (GM) (Hakulinen \& Auvinen, 2014), which is also known as 'verbs of gamification' (Nielson, 2017). GM is also how students engage with the program, the next steps to undertake, and what form of accomplishment feedback is received, which usually takes place in forms such as points, badges, AND leaderboards (PBL) (Werbach \& Hunter, 2015), mission levels, and progress (observations and rewards). Moreover, of the 24 GM characteristics listed in 2017 by Nielson (2017), the author stated that they could be divided into three distinct categories or attributes: the GM type, boosts or benefits, and finally, types of personalities (Nielson, 2017).

Furthermore, although there is a thin line between GM and 'game dynamics' (GD), GD is interpreted to be understood as the tools within the game that creates satisfaction in the player (Werbach \& Hunter, 2015). This is consistent with Hamari and Koivisto (2015), who noted that hedonic motivations are positively associated with a user's gamification continued use. In Finland, Hassan et al. (2019) also reported that gamification is positively associated with a player's experiences of affective feedback. There is more GM than GD, with GM acting as the tool helping the player move forward within the simulation. Specifically, Werbach and Hunter (2015) outlined five GDs, including constraints, emotions, the narrative, progression, and progression. Moreover, 'emotions' come from the positive or negative results from the game's simulation.

\subsection{Creative and critical thinking}

Discussions concerning critical thinking (CT) are nearly as old as civilization itself, with Plato 2,500 years ago in his lectures concerning logic believed that CT was a tool from which people could find solutions or answers to confusion or problems (Thayer-Bacon, 1998). Socrates, Plato's teacher, also believed that CT and discussion with knowledge reside in an individual's mind, instead of with the transmission of knowledge from teacher to student (Ornstein \& Levine, 2006). After 2,500 years, 
countless scholars have written and lectured on the processes, importance, and outcomes of CT skills (or lack thereof) (Changwong et al., 2018).

In the U.S., the National Association of Colleges and Employers (NACE) (2016) highlighted the importance CT skills after their survey of employees found that the respondents felt that CT skills were the most importance skill in a new hire. Similarly, Bassham et al. (2013) reported that university educators have a responsibility to develop student CT skills, which in turn lead to higher-order thinking skills (HOTS). Additionally, HOTS uses concept formation, CT, creativity and brainstorming, problem-solving, mental representation, rule use, reasoning, and thinking logically (Srikan et al., 2021). This is also consistent with other studies in which CT skills are consistently included as a requirement for university and career readiness (Costa \& Kallick, 2014; National Council for Excellence in Critical Thinking, 2017).

However, unfortunately in Thailand CT skills seem to be a missing element in secondary skill school children, as recent evaluations of 6,235 students across 10 Thai provinces on their logical thinking and analytical skills discovered that only $2.09 \%$ could pass the exam (Rujivanarom, 2016). Comments and speculation as to why these scores are so low are numerous, but the reality of the problem is there for all to see.

Fortunately, numerous scholars from their STEM and STEAM research have come to the conclusion that both initiatives are an excellent way in which students gain knowledge, creatively and solve problems across disciplines, both in the classroom and out (Gess, 2017; Henriksen, 2014; Liao, 2016; Rahmawati et al., 2019; Ugras, 2018). Moreover, Holm-Hadulla (2010) has added that scientific thinking requires creative ability, while Henriksen (2014) has also found that STEM curricula benefit from the arts' creative aspects and solutions. Other scholars have established connections between ICT and innovation and the need to possess $21^{\text {st }}$ Century skills such as creativity and critical thinking, problem-solving abilities, research and questioning skills, and finally, collaboration skills to be successful (Morrison, 2006; Wai et al., 2010). Finally, most importantly according to Conradty and Bogner (2018), thinking creatively is paramount in solving problems..

\section{Research methodology}

The investigation into how a VCLE affects the STEAM education process of Thai university students and their creative skills, critical thinking skills, and innovation skills used a mix-method research approach, which included both quantitative and qualitative methods. Moreover, we undertook a systematic review to investigate which factors affect the STEAM-ification process in a VCLE (Wahono et al., 2020).

\subsection{Qualitative review}

In the qualitative analysis, we set out first to find the most recent studies (five years or less) concerning STEAM and STEM education using the following steps: 
Step 1: The researchers synthesized the model after a review of 170 documents. Step 2: The primary researcher developed the VCLE STEAM-ification model after consultation with his advisor. After that, the model was presented to a Focus group of 19 experts for their comments, suggestions, model quality assessment and suitability (Nyumba et al., 2018; Ruenphongphun et al., 2021; Srikan et al., 2021; Tremblay et al., 2012).

Step 3: The researcher then used the proposed VCLE STEAM-ification model to experiment with students (This data is not included in this article due to its extensive and supplemental nature).

Keyword searches combined with STEAM included creativity, critical thinking, innovation, gamification, virtual classroom, virtual learning, and learning environment. According to Lawrence et al. (1999), keywords research is necessary for finding articles. This was then repeated using these terms combined with STEM. This is consistent with Cohen et al. (2007), who have suggested that meta-analysis-type methods are an excellent way to synthesize findings from separate studies and allow researchers to compare, combine, and subsequently evaluate quantitative data taken from these studies to obtain more complete and convincing results.

\subsection{Ethics clearance}

Ethics approval for the study was obtained from our university's Human Ethics Committee before consultation with the two groups of 19 experts relating to the questionnaire's design and assessment (P1mdee, 2020). Before the Zoom meeting with each panel of experts, each individual was sent via email a simple and clear explanation about the purposes of the research and informed that the information obtained was confidential and no identities would be disclosed. Email confirmation and agreement were then noted from each individual. Furthermore, all data obtained from the respondents was stored in a password-protected computer and secure location.

\subsection{Design of the STEAM education process}

The design of the study's model was undertaken by a panel of nine experts in which in-depth interviews were used to assess each participant's opinions concerning the study's quantitative results related to STEAM education, creativity, critical thinking, innovation, and how all this is affected by the use of a VCLE. Furthermore, each expert selected via purposive sampling had a minimum of a Ph.D. and five years of related teaching expertise in their field. The disciplines of each individual were related to the fields of ICT, education technology, gamification, teaching design, virtual classrooms, or organizational learning concepts. Due to the ongoing global Covid-19 pandemic in 2020 at the time of the study, all meetings related to the study were undertaken using Zoom video-conferencing software (Li et al., 2021). 


\subsection{Development and evaluation of the VCLE STEAM-ification model}

\subsubsection{Development of VCLE STEAM-ification model}

The second group of 10-panel education experts was selected via purposive sampling in late 2020 to review the appropriateness of the STEAM education model from both our input and that of the last panel of nine experts. Once again, the second group of experts had a minimum of a Ph.D. and five years of teaching experience in their respective disciplines. Their fields of expertise included ICT, education technology, teaching design with gamification, organizational learning environments, virtual classrooms, curriculum development, and measurement and evaluation.

Each was given a survey of items in which a five-level scale was used to determine their level of agreement in their assessment. The questionnaire scale interpretation made use of ' 5 ' as a very positive response (4.50 - 5.00), '4' indicated a positive response (3.50 - 4.49), ' 3 ' was somewhat positive $(2.50-3.49)$, ' 2 ' was a negative response (1.50 - 2.49), and finally, ' 1 ' was determined to be a very negative (1.00 - 1.49) response (P1mdee, 2020; Rajaram, 2021).

\subsection{Data collection}

The researchers collected the data by following the following three steps in sequence:

\subsubsection{Preparation before the expert panel discussion}

The researchers first discussed with the panel of experts on how to deliver a simplistic learning process using a flipped-classroom environment which would foster creativity and innovation among Thai undergraduate students. A creativity assessment form and a form to assess the suitability of the creative innovation process were developed.

\subsubsection{Discussion proceedings}

A small group meeting was held on August 22, 2019, from 10:00-16:00, in meeting room 212 at the Science and Technology Research Office within the King Mongkut's University of Technology North Bangkok campus to provide feedback on the learning process using a flipped-classroom online learning environment to foster creativity and innovation among Thai undergraduate students. Also, the meeting had a goal to create forms to aassess student creativity and creative innovation. 


\subsubsection{Post-conversation and expert check}

In this phase, we assessed the consistency of the creativity assessment scale and the consistency of the creative innovation assessment form.

\subsection{Data analysis}

The analysis of the level of suitability of the model (VCLE STEAM-ification) used the following steps:

\subsubsection{Evaluation of suitability of the VCLE STEAM-ification model}

The population were second semester undergraduate students in the third year of studies in the Faculty of Science and Technology at Rajamangala University of Technology Suvarnabhumi, Thailand in 2019. At this time, there were 820 students spread across six disciplines. The sample was obtained by using multistage random sampling in the following manner:

$1^{\text {st }}$ time: Cluster random sampling was done by specifying disciplines in the Faculty of Science and Technology at Rajamangala University of Technology Suvarnabhumi as a random unit with a lottery method, which became the sample group of 'Multimedia Technology'.

$2^{\text {nd }}$ time, Systematic random sampling was then used from the list of students in the multimedia technology department in which the odd numbers became the study's experimental group and the even numbers became the control group of 30 students who continued to study using traditional methods.

\subsection{The tools used in the research}

The tools used in the research consisted of:

\subsubsection{Creativity assessment form}

The creativity assessment form used concepts adapted from Guilford. (1991) and Nitko (2004) and consists of four sub-skills including originality, fluency, flexibility, and elaboration. A Rubrics scoring criterion was also used which contained a 4-level scale which was determined to have a consistency index between $0.80-1.00$, a difficulty between $0.27-0.79$, and a power of discrimination of 0.82 .

\subsubsection{Creative Innovation Assessment Form}

Developed from the concepts outline by the OECD and Eurostat (2005), Smith (2006) and Weyrauch and Herstatt (2016), the creative innovation assessment form consisted of five parts. There were 1) being novel and unique 2) solving 
objectives 3) efficiency 4) feasibility of use (Possibility) and 5) cost. The outcome from the experts's input using a Rubrics score on a 4-level scale, was a consistency index score from 0.80 - 1.00, a difficulty level form $0.23-0.77$, and a classification power of 0.81 .

\subsection{Data collection}

The experiment was conducted with students in the course titled Courseware Design and Development during the Academic Year 2019 for 8 weeks.

\section{Research findıngs}

\subsection{The STEAM education process using a VCLE}

From the quantitative method analysis and the selection of aspects frequently associated with creativity, critical thinking, and innovation in the scholarly literature, we found that multiple researchers in Table 1 discussed investigation, discovery, connections, creativity, and reflection as five primary steps. Moreover, these five steps are shown in Figure 1.

Table 2 further details the synthesis of the results of the gamification components. We find that there are three primary elements: the GM, the GD, and the player's emotions (Jia et al., 2016; Ortiz et al., 2016; Werbach \& Hunter, 2015). Also, from the input from Toda et al. (2019), the study's specifics were drawn from a single classroom test case of 40 programming course class members. Ding (2019) undertook a gamification study with 70 online students, moving out of the realm of STEAM into the social science discipline of political science. The author concluded, like others, that student gamification familiarity was a factor in the success of the exercise and that in this test case, promoting a student's sense of community was not successful. This is somewhat similar to Sanchez et al. (2019), who took an even larger sample group of 473 university undergraduates and noted that their

Table 1 A representative overview of the quantitative method analysis of the STEAM education process

\begin{tabular}{|c|c|c|c|c|c|c|c|}
\hline $\begin{array}{l}\text { STEAM } \\
\text { Education } \\
\text { Process }\end{array}$ & $\begin{array}{l}\text { (Rahmawati } \\
\text { et al., 2019) }\end{array}$ & $\begin{array}{l}\text { (Perignat \& } \\
\text { Katz-Buon- } \\
\text { incontro, } \\
2019 \text { ) }\end{array}$ & $\begin{array}{l}\text { (How \& } \\
\text { Hung, } \\
2019 \text { ) }\end{array}$ & $\begin{array}{l}\text { (Baharin } \\
\text { et al., } \\
\text { 2018) }\end{array}$ & $\begin{array}{l}\text { (Ugras, } \\
\text { 2018) }\end{array}$ & $\begin{array}{l}\text { (Ogun- } \\
\text { leye, } \\
2018)\end{array}$ & $\begin{array}{l}\text { STEAM } \\
\text { Education } \\
\text { Process }\end{array}$ \\
\hline $\begin{array}{l}\text { Investiga- } \\
\text { tion }\end{array}$ & $\sqrt{ }$ & $\sqrt{ }$ & $\sqrt{ }$ & $\sqrt{ }$ & $\sqrt{ }$ & $\sqrt{ }$ & $\sqrt{ }$ \\
\hline Discover & $\sqrt{ }$ & $\sqrt{ }$ & $\sqrt{ }$ & $\sqrt{ }$ & $\sqrt{ }$ & $\sqrt{ }$ & $\sqrt{ }$ \\
\hline Connect & $\sqrt{ }$ & $\sqrt{ }$ & $\sqrt{ }$ & $\sqrt{ }$ & $\sqrt{ }$ & $\sqrt{ }$ & $\sqrt{ }$ \\
\hline Create & $\sqrt{ }$ & $\sqrt{ }$ & $\sqrt{ }$ & $\sqrt{ }$ & $\sqrt{ }$ & $\sqrt{ }$ & $\sqrt{ }$ \\
\hline Reflect & $\sqrt{ }$ & $\sqrt{ }$ & $\sqrt{ }$ & $\sqrt{ }$ & $\sqrt{ }$ & $\sqrt{ }$ & $\sqrt{ }$ \\
\hline
\end{tabular}


Fig. 1 The STEAM education process

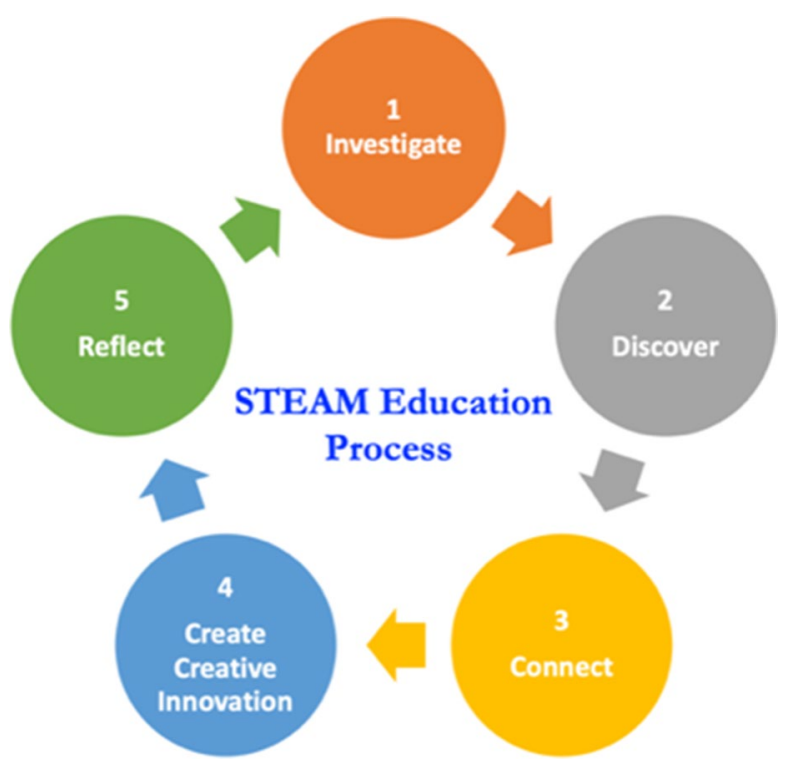

gamification exercises were not sustainable after the novelty wore off for their students. Also, higher achievers did better than lower achievers overall (Table 6).

Furthermore, Koivisto and Hamari (2019) undertook a comprehensive review of 819 gamification studies and reported that while results generally were favorable, it was remarkable to find a wide array of mixed results. They also added that badges, points, and leaderboards persisted as the most common contexts and ways of implementing gamification (Table 2). Additionally, Hakaket et al. (2019) addressed the specifics of using gamification within the 'cloud' and further elaborated on subject areas that the authors felt were conducive to gamification through cloud services. Finally, Rodrigues et al. (2019) similarly examined 50 gamification studies and, from the Leximancer text mining tool, diagramed 28 gamification concepts, which were then grouped as eight themes. Figure 2 shows this study's gamification components including the game mechanics, the game dynamics, and game emotion.

\subsection{The creative thinking and creative innovation STEAM education process using a VCLE}

Figure 4 details the results from quantitative analysis and the panels of experts' input into the STEAM education process for Thai undergraduate creative thinking and creative innovation development using a VCLE. The model determined that there were five primary elements: investigate, discover, connect, create, and reflect. Furthermore, Fig. 3 details both the GMs and the GDs associated with each step's element. Game mechanics involve determining goals, collecting points, enhancing levels, gaining badges and the leaderboard, whereas game dynamics involve demanding rewards, desiring the achievement, and competition and challenges (Table 3). Finally, a gamified VCLE consists of both the concrete and abstract environments 


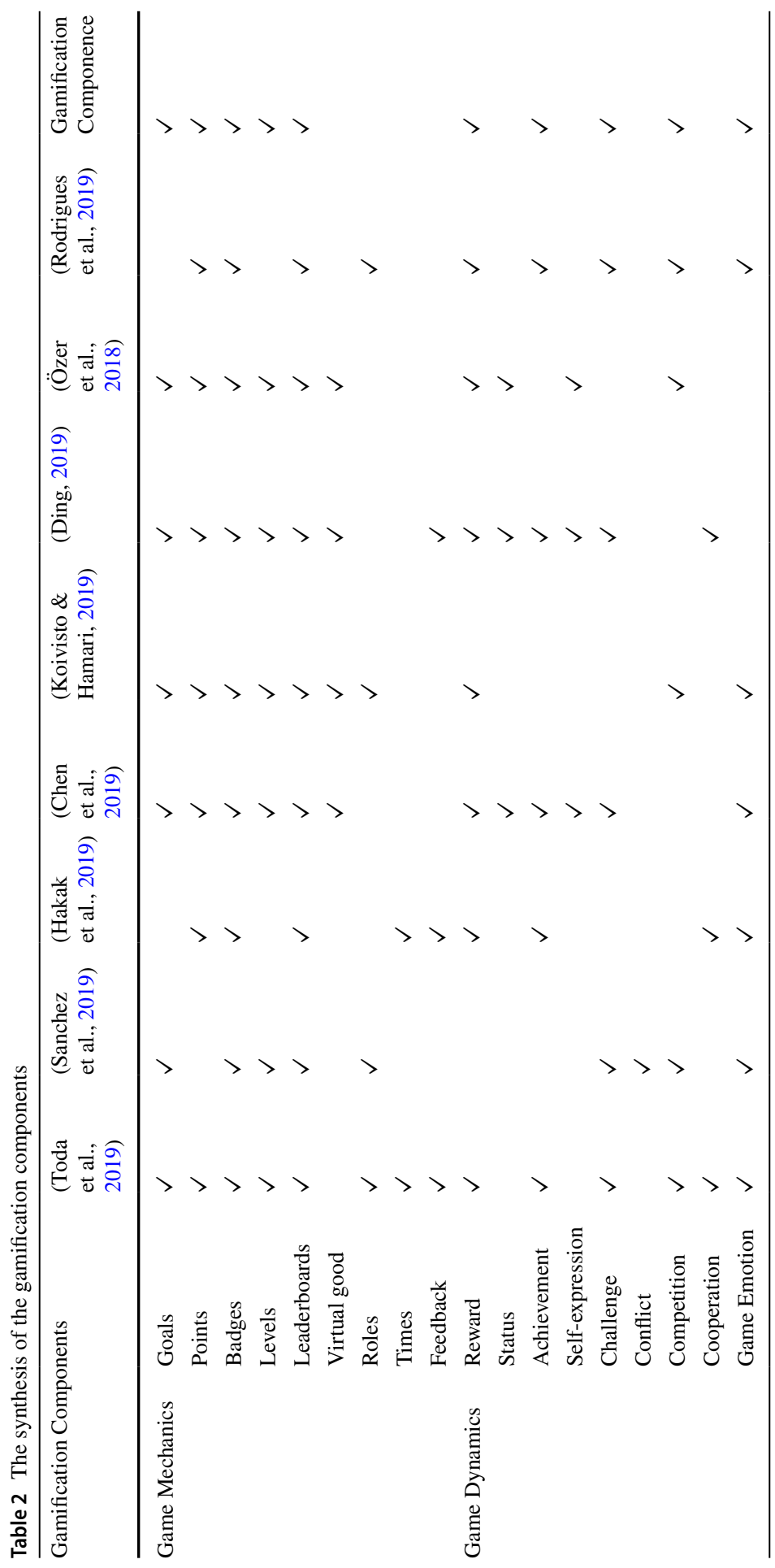




\section{Gamification Components}

\begin{tabular}{|l|l|}
\hline Game Dynamics & Game Mechanics \\
\hline (8) Reward & (9) Goals \\
(8) Achievement & Point \\
(18) Challenge & Badges \\
(8) Competition & (8) Leaderboards \\
& (3) Level \\
& $\approx$ Game Emotion
\end{tabular}

Fig. 2 The gamification components

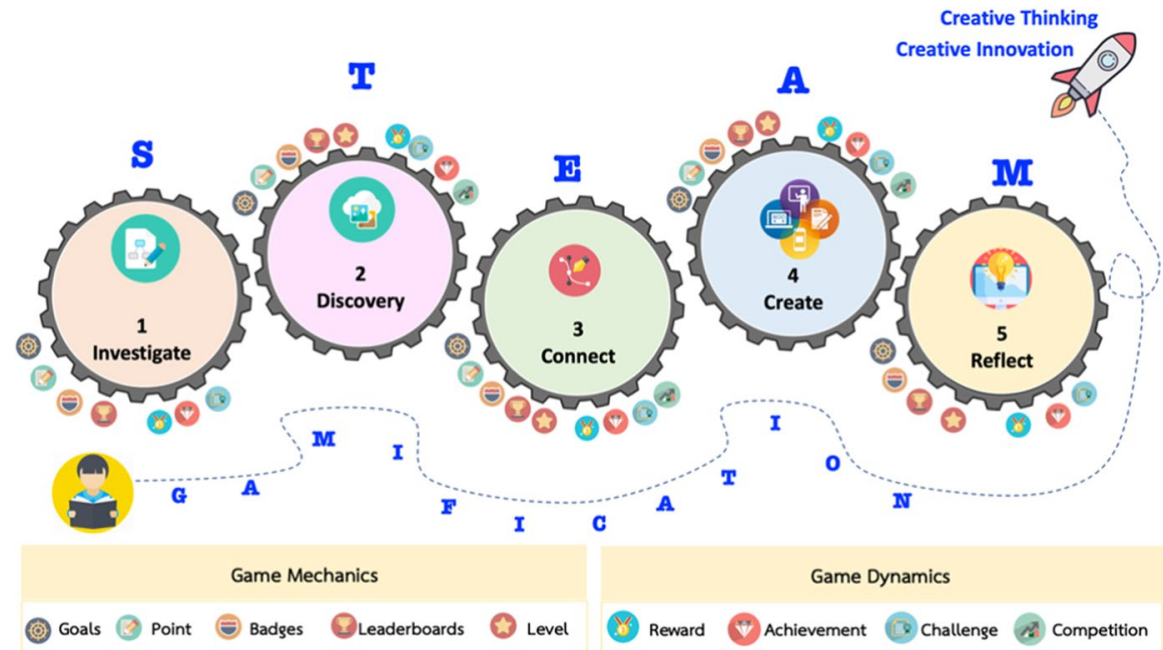

Fig. 3 The STEAM education process step GMs and GDs

concerned with face-to-face classroom learning and the out-of-class, online learning process, respectively (Table 4 and Figure 4).

\subsection{The evaluation of the appropriateness of the STEAM-ification process using a VCLE}

Table 5 details the results from the panel of 10 experts who gave input on the appropriateness of the STEAM-ification learning process using a VCLE. We note that the conceptual model's digital support to support learning and the application of the 


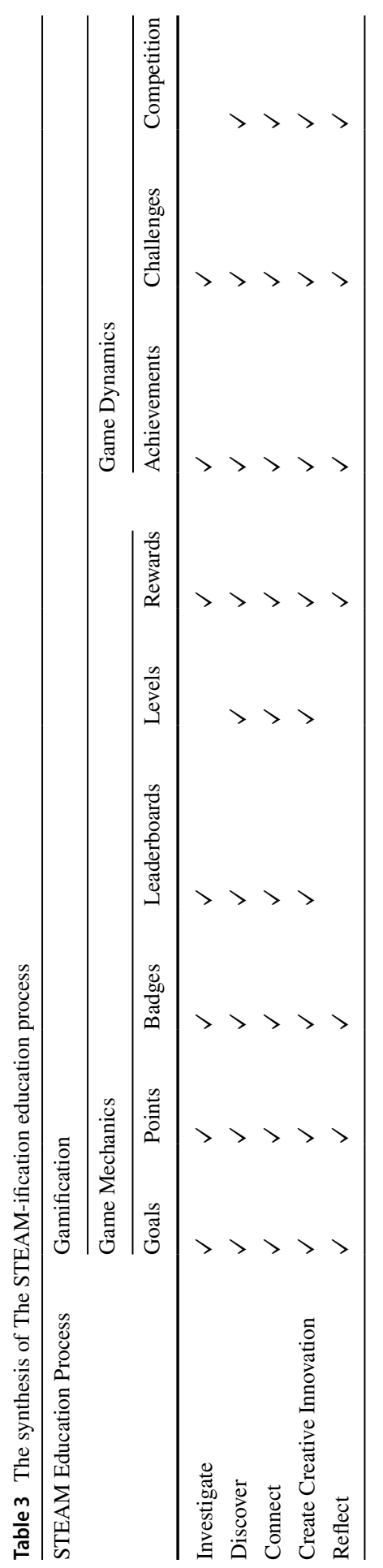




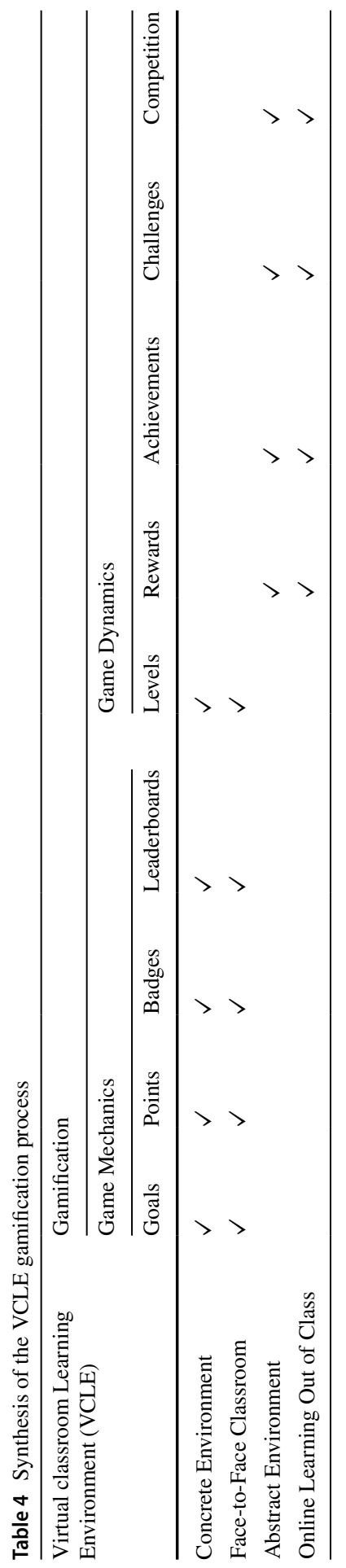




\section{Virtual Classroom Learning Environment}

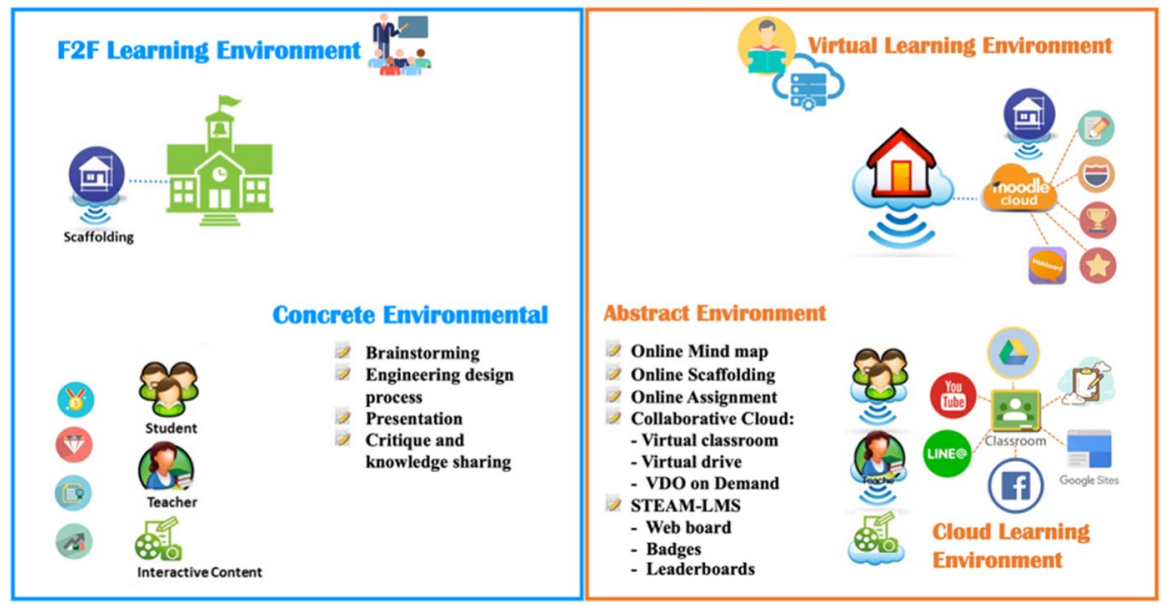

Fig. 4 The VCLE's concrete and abstract aspects

Table 5 Conceptual model appropriateness determination from the panel of experts $(n=10)$

\begin{tabular}{llll}
\hline Content & $\bar{x}$ & S.D. & Appropriateness Level \\
\hline The STEAM-ification education learning process & 4.70 & 0.48 & Excellent \\
VCLE & 4.70 & 0.48 & Excellent \\
Digital technology to support learning & 4.80 & 0.42 & Excellent \\
Promoting creativity & 4.40 & 0.52 & Very good \\
Promoting creative innovation development & 4.70 & 0.48 & Excellent \\
Applying STEAM-ification processes in a VCLE & 4.80 & 0.42 & Excellent \\
Overall appropriateness & 4.68 & 0.47 & Excellent \\
\hline
\end{tabular}

STEAM-ification process in a VCLE were both ranked as the highest and 'excellent' in from the five-level agreement scale use. However, the conceptual model's ability to promote creativity was at the bottom of the scale, which was still ranked as 'very good.' Overall, the six aspects identified from the experts' evaluation study were ranked as 'excellent' $(\overline{\boldsymbol{x}}=4.68, \mathrm{~S} . \mathrm{D} .=0.47)($ Chujitarom, 2020).

\subsection{VCLE STEAM-ification student assessment}

Table 6 shows the results from both the experimental and control groups on student creative thinking and creative innovation.

From Table 1, it was determined that the experimental group using the VCLE STEAM-ification model had an average score of creativity. However, the researcher could not conclude whether it was a statistically significant increase or not, therefore, the One-Way MANOVA statistic had to be tested further. 
Table 6 Mean and standard deviation of creativity and creative innovation

\begin{tabular}{|c|c|c|c|c|c|c|c|}
\hline \multirow[t]{2}{*}{ Groups } & \multirow[t]{2}{*}{$\mathbf{n}$} & \multicolumn{3}{|c|}{ Creative Thinking } & \multicolumn{3}{|c|}{ Creative Innovation } \\
\hline & & Total score & $\bar{x}$ & SD & Total score & $\bar{x}$ & SD \\
\hline Experimental & 30 & 16 & 14.53 & 0.94 & 20 & 18.40 & 1.04 \\
\hline Control & 30 & 16 & 12.87 & 1.92 & 20 & 14.86 & 1.62 \\
\hline
\end{tabular}

Before conducting the One-Way MANOVA statistical test, the researchers conducted a preliminary agreement test as follows (Bray \& Maxwell, 1985).

1. Test the normal distribution of the data (Normality) with the Shapiro-Wilk test. It was found that the data for both dependent variables had a normal distribution $(\operatorname{Sig}>\alpha)$.

2. Testing the variance-covariance metrics (testing homogeneity of covariance matrices) with Box's M Test statistic found that the variance metrics of the two groups were not different (Sig. $>\propto$ ).

3. Test the relationship between the dependent variables (multi-linearity: multicollinearity) by using Barlett's Test of Sphericcity, From this evaluation it was found that the dependent variables were statistically significantly related $($ Sig. $<\propto)$.

From Table 7, it was found that the experimental group using the VCLE STEAM-ification model had an average score for creativity but for creative innovation it was higher than the control group that used the normal learning management plan. It was also found that the creativity of the experimental group was higher than the control group. The statistical significance was at the .01 level

Table 7 Results of multiple variance analysis to compare creativity and creative innovation of students in experimental and control groups

\begin{tabular}{lllllll}
\hline variance source & Multivariate tests & Value & F & Sig. & \\
\hline Group & Pillai's Trace & 0.69 & $63.36^{* *}$ & 00 & \\
& Wilks' Lambda & 0.31 & $63.36^{* *}$ & 00 & \\
& Hotelling's Trace & 2.22 & $63.36^{* *}$ & 00 & & \\
& Roy's Largest Root & 2.22 & $63.36^{* *}$ & 00 & & \\
Test of Between-Subjects Effects & & & & & Sig. \\
Source & Dependent Variable $>$ & SS & df & S & F \\
Group & creativity & 188.43 & 1 & 88.43 & $128.94^{* *}$ & .00 \\
& creative innovation & 38.37 & 1 & 8.37 & $25.39^{* *}$ & .00 \\
Error & creativity & 84.76 & 58 & .46 & & \\
& creative innovation & 87.63 & 58 & .51 & & \\
Total & creativity & 16862.95 & 60 & & & \\
& creative innovation & 11388.49 & 60 & & & \\
& & & & & & \\
\hline
\end{tabular}

$* *$ Sig. $<.01$ 
$(\mathrm{df}=1, \mathrm{~F}=128.94, p=.00)$ and the creative innovation of the experimental group was higher than the control group. It was also statistically significant at the .01 level $(\mathrm{df}=1, \mathrm{~F}=25.39, p=.00)$.

\section{Virtual Learning Environment}

\section{Online Learning Dnvironment Ienen}

2.1 Learners brainstorm and plan $(\mathbf{S}, \mathbf{T})$

2.2 Each learner searches for the information $(\mathbf{S}, \mathbf{T})$ 2.3 Learners present information $(\mathbf{S}, \mathbf{T})$

2.4 Teachers evaluate the learners' work and give feedback $(\mathbf{S}, \mathbf{T})$

2.5 STEAM-LMS gives the badge to the next level and notice on the leadership board automatically (T) 00000000

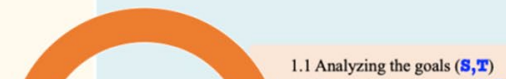

1.2 Determining the goals $(\mathbf{S}, \mathbf{T})$
1.3 Determining the topics $(\mathbf{S}, \mathbf{T})$

1

1.4 Present results of analysis $(\mathrm{S}, \mathbf{T})$

1.5 Teachers evaluate the learners' work (T)

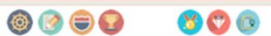

3

.1 Learners brainstorm about connecting information for which they searched (S,T) 3.2 Learners present information with mind mapping $(\mathbf{S}, \mathbf{T}, \mathbf{A})$

2

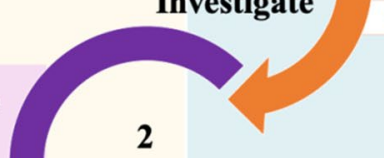

Connect 3.3 Teachers evaluate the learners' work then give
feedback (S,T)

Connect
$\begin{aligned} & 3.3 \text { Teachers evaluate the learners' work then give } \\ & \text { feedback (S,T) }\end{aligned}$
3.4 STEAM-LMS gives the badge and notice on

4.1 Analysis of the goals $(\mathbf{S}, \mathbf{T})$

4.2 Design flowchart, storyboard $(\mathbf{S}, \mathbf{T}, \mathbf{E}, \mathbf{A})$

4.3 Develop creative innovation ( $\mathbf{S}, \mathbf{T}, \mathbf{E}, \mathbf{A})$

4.4 Implement innovation in classroom (S,T, $\mathbf{E}, \mathbf{A})$

4.5 Evaluate the creative innovation $(\mathrm{S}, \mathrm{T}, \mathrm{M})$

4. 6 Learners present the creative innovation processes ( $\mathbf{T}, \mathbf{A}, \mathbf{M}$ )

4.7 Teachers evaluate the learners' works then give feedback (T)

4.8 STEAM-LMS gives the badge and notice on the leadership board (T)

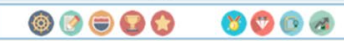

\section{5} the leadership board $(T)$

\section{Create}

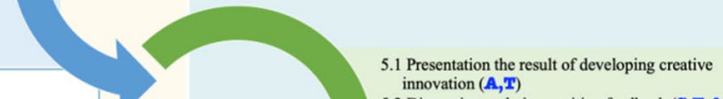

5.2 Discussion and give positive feedback $(\mathrm{S}, \mathrm{T}, \mathrm{A})$ 5.3 Reflect on learning $(\mathbf{S}, \mathbf{T})$

\subsection{Conclusion $(\mathrm{S}, \mathrm{T})$ \\ Reflect \\ 5.5 Record the reflection on learning $(S, T)$ \\ 5.6 STEAM-LMS gives the badge and notice on the leadership board $(T)$}

(1) $\odot 00000$

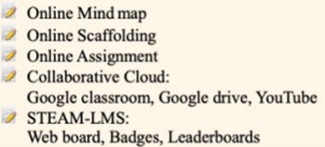

Web board, Badges, Leaderboards

2 Brainstorming

Engineering design proces

2. Presentation

Critique and knowledge sharing Online Learning Tools

\section{F2F Classroom Tools}

Fig. 5 The final conceptual model of a VCLE being used for STEAM education creative thinking and innovative thinking process development 


\subsection{Final conceptual model}

Figure 5 details the final results of the study. We can see the five elements and their associated aspects and sub-steps used within the VCLE.

\section{Discussion}

The STEAM education process in a VCLE consisted of five steps: investigate, discover, connect, create, and reflect. Moreover, gamification consisted of two main elements: game mechanics (e.g., goals, point, level, badges, and leaderboards) and game dynamics (e.g., rewards, achievement, challenges, and competition). Furthermore, from the panel of ten experts' input, it was determined that the proposed STEAM education model was an excellent foundation in the development of tools necessary for use in a digitally-based education LMS, flipped classroom, or blended learning environment (Banyen et al., 2016; DeLozier \& Rhodes, 2017; Wannapiroon \& Petsangsri, 2020).

\subsection{VCLE}

In New Zealand, VCLE student research by Gedera (2014) added that the use of digital platforms to connect with the Internet to websites where VCLEs are being used in blended learning environments is an excellent way for a student and teacher interaction which mimics an actual physical classroom. This study's conceptual model is also consistent with Fukuda et al. (2018), who in Japan developed a model for a VCLE in which the authors detailed their model's use of the need for student-centered ICT use, collaboration and social networking, and the site's ability for interactivity use.

The authors also suggested that the teaching and learning process is therefore not a journey to study in the cclassroom but rather a way to access the lesson's content through ICT and digital devices. In the United States, Hou et al. (2017) also investigated the cloud-based use of VCLEs, from which they detailed the complexities and calculations of Internet bandwidth capability and lesson streaming. Their suggestion was that to overcome bitrate requirements, VCLEs should employ hyper-cast approaches for cloud-based applications.

\subsection{STEAM education}

Based on the research results by Morrison (2006) in the United States, STEM was found to enhance student creativity, their ability at creative design, and the production of solutions based on current needs. This is consistent with Bakar and Mahmud (2020), who detailed the national government's stated importance of STEM and TVET education in Malaysia.

Moreover, the findings suggested that it was in the government's best interest to expose students to these educational tracts as early as the lower secondary school 
level and to provide counseling services in career development programs for both fields. Also, the authors suggested that STEAM education can help learners solve problems in their daily lives while enhancing their experiences, life skills, and creativity. STEAM education also motivates students to take up later industry positions that employ their science, mathematics, and technology skills. Thus, they can use this knowledge to create innovation (Ogunleye, 2018; Parmin et al., 2020; Techakosit \& Wannapiroon, 2015). Finally, STEAM education encourages learners to do activities that allow them to apply these skills to design processes or work to solve problems in daily life (Baharin et al., 2018; Rahmawati et al., 2019).

\subsection{Gamification}

In Thailand, Chujitarom (2020) found that collaborative gamification was a highly useful method in promoting innovative student creativity in digital art classes, with a knock-on effect of knowledge creation and innovation, which could be applied in the workplace. This is consistent with Santosa et al. (2020) in Indonesia, who also found that mobile digital devices used in ICT-supported collaborative learning were excellent at improving learning outcomes and solving problems. Once again, learners who were self-motivated at learning achieved better results.

Furthermore, in Taiwan, Hsu et al. (2017) noted the critical nature of website design in gamification's successful outcome. They also indicated that the site's utilitarian and hedonic features significantly affected a player's experience. In Cyprus, Hursen and Bas (2019) discussed the use of gamification in science education and found that within their class of 16 science students, motivation was increased and there was a joint approval from both the students and their parents.

\subsection{Creative, critical thinking and innovation skills}

The study's inclusion of creative thinking, critical thinking, and innovative skills as an output from a well-developed VLCE used in STEAM education was well supported in the literature from around the world (Choolarb et al., 2019; Chujitarom, 2020; Chujitarom \& Piriyasurawong, 2018; Ding, 2019; Jantakoon et al., 2019; Kankaew \& Wannapiroon, 2019; Perignat \& Katz-Buonincontro, 2019; Ruangvanich \& Nilsook, 2018; Santosa et al., 2020; Sayavaranont \& Piriyasurawong, 2019).

\section{Conclusion}

Significant and global support was found for the study's investigation and conceptual model into how a VCLE affects a Thai undergraduate student's creative thinking, critical thinking skills, and innovation from the STEAM education or 'STEAM-ification' process. Furthermore, although there are also extensive global studies on gamification, the success of gamification is dependent on a variety of factors, including technological (e.g., bit rates and streaming), site design, the method and use of game mechanics and game dynamics, and the emotional 
aspects which contribute most to a highly pleasurable, hedonic experience. Finally, when undertaken correctly, innovation and motivation to learn are also outcomes from both VCLE and gamification implications.. Students who study with the VCLE STEAM-ification format are more creative and creative innovation is higher than the students who study according to the normal teaching plan.

\section{Limitations and future recommendations}

The first limitation for the study's conceptual model development is how creative thinking or creativity is defined, their criteria, and concepts, as there is no single definition for neither. Second, many technological factors are necessary for a VCLE or gamified environment to work effectively and smoothly. In countries like Thailand, especially in rural areas, implementation and success might be difficult, if not impossible, to achieve. As was noted throughout the paper, there has been an evolution from STEM to STEAM, with the addition of 'art' being somewhat hard to define and what context in which it used. Also, throughout the study's research, the issue of 'gender' was often discussed and evaluated within the context of STEAM and gamification. However, these results are mixed and somewhat unclear. It is suggested that similar studies address the issue of gender's role in a successful STEAM and gamification implication. Also, future studies might conduct a deeper analysis of which players perceive digital devices as most useful and why this is so.

Acknowledgements The authors wish to thank Assistant Professor Dr. Wannaporn Chujitarom for reviewing the manuscript multiple times and making recommendations for improvement. Additionally, sincere thanks go to Ajarn Charlie for his English language editing and proofing.

Data availability The data and materials that support the findings of this study are available from the corresponding author upon reasonable request.

Authors' contributions Conceptualization, N.W.; Software, P.P; Validation, N.W. and P.P; Formal analysis, N.W. and P.P; Investigation, N.W.; Resources, N.W.; Writing-original draft preparation, N.W.; Writing-review and editing, N.W. and P.P; Supervision, P.P. Both authors have read and agreed to the published version of the manuscript.

Funding This research was supported by the Faculty of Science and Technology, Rajamangala University of Technology Suvarnabhumi, Thailand and the Department of Industrial Education, Faculty of Industrial Education and Technology, King Mongkut's Institute of Technology Ladkrabang (KMITL), Thailand.

\section{Declarations}

Consent to participate Informed consent was obtained from the two panels of experts (19 individuals total) involved with this study.

Consent for publication The experts have consented to the submission of their input to the journal.

Conflicts of interest The authors declare there is no conflict of interest. 


\section{References}

Alismail, H. A. (2015). Integrate digital storytelling in education. Journal of Education and Practice, 6(9), 126 - 130. https://tinyurl.com/htsysrun

Baharin, N., Kamarudin, N., \& Manaf, U. K. A. (2018). Integrating STEM education approach in enhancing higher order thinking skills. International Journal of Academic Research in Business and Social Sciences, 8(7), 810-821. https://doi.org/10.6007/IJARBSS/v8-i7/4421

Bakar, A. Y. A., \& Mahmud, M. I. (2020). Profiling of aspiration and interest towards STEM and TVET careers among lower secondary students: A Malaysian case study. Journal for the Education of Gifted Young Scientists, 8(1), 489-500. https://doi.org/10.17478/jegys.669034

Banyen, W., Viriyavejakul, C., \& Ratanaolarn, T. (2016). A blended learning model for learning achievement enhancement of Thai undergraduate students. International Journal of Emerging Technologies in Learning, 11(04), 48-55. https://doi.org/10.3991/ijet.v11i04.5325

Bassham, G., Irwin, W., Nardone, H., \& Wallace, J. M. (2013). Critical thinking: A student's introduction (5th ed.). McGraw-Hill.

Baxter, W. (2017). Thailand 4.0 and the future of work in the Kingdom. International Labour Organization. http://tinyurl.com/mkhf5r5

Bazler, J., \& Sickle, M. V. (2017). Cases on STEAM education in practice. IGI global. https://doi.org/ 10.4018/978-1-5225-2334-5

Bertrand, M. G., \& Namukasa, I. K. (2020). STEAM education: student learning and transferable skills. Journal of Research in Innovative Teaching \& Learning, 13(1), 43-56. https://doi.org/10. 1108/JRIT-01-2020-0003

Boholano, H. B. (2017). Smart social networking: 21st Century teaching and learning skills. Research in Pedagogy, 7(1), 21 - 29. 10.17810/2015.45

Bray, J., \& Maxwell, S. (1985). Multivariate analysis of variance. Sage.

Carlile, O., \& Jordan, A. (2012). Approaches to Creativity: A Guide for Teachers. Open University Press.

Catchen, R. (2013). Reflections How STEM becomes STEAM. STEAM, 1(1), 1-4. https://doi.org/ $10.5642 /$ steam.201301.22

Chaffar S., \& Frasson C. (2012). Affective dimensions of learning. In N. M. Seel N.M. (Ed.), Encyclopedia of the Sciences of Learning. Springer. doi: 10.1007/978-1-4419-1428-6_113

Changwong, K., Sukkamart, A., \& Sisan, B. (2018). Critical thinking skill development: Analysis of a new learning management model for Thai high schools (2018). Journal of International Studies, 11(2), 37-48. https://doi.org/10.14254/2071-8330.2018/11-2/3

Chen, C. M., Li, M. C., \& Chen, T. C. (2019). A collaborative reading annotation system with gamification mechanisms to improve reading performance. Proceedings - 2018 7th International Congress on Advanced Applied Informatics, IIAI-AAI 2018, 144, 188 - 193 doi: 10.1109/ IIAI-AAI.2018.00044.

Choolarb, T., Premsmith, J., \& Wannapiroon, P. (2019). Imagineering gamification using interactive augmented reality to develop digital literacy skills. ACM International Conference Proceeding Series, 39 - 43. doi: 10.1145/3369199.3369222

Chujitarom, W. (2020). Digital storytelling through teamwork gamification model to encourage innovative computer art. TEM Journal, 9(2), 560-565. https://doi.org/10.18421/TEM92-18

Chujitarom, W., \& Piriyasurawong, P. (2018). STEAM-GAAR field learning model to enhance grit. International Education Studies, 11(11), 23-33. https://doi.org/10.5539/ies.v11n11p23

Cohen, L., Manion, L., \& Morrison, K. (2007). Research methods in education (6th. ed.). Routledge https://tinyurl.com/xp48chhf

Connor, A. M., Karmokar, S., \& Whittington, C. (2015). From STEM to STEAM: Strategies for enhancing engineering \& technology education. International Journal of Engineering Pedagogy, 5(2), 37 - 47 doi: 10.3991/ijep.v5i2.4458.

Conradty, C., \& Bogner, F. X. (2018). From STEM to STEAM: How to monitor creativity. Creativity Research Journal, 30(3), 233-240. https://doi.org/10.1080/10400419.2018.1488195

Costa, A., \& Kallick, B. (2014). Dispositions: Reframing teaching and learning. Corwin Press.

Darling-Hammond, L., Flook, L., Cook-Harvey, C., Barron, B., \& Osher, D. (2020). Implications for educational practice of the science of learning and development. Applied Developmental Science, 24(2), 97-140. https://doi.org/10.1080/10888691.2018.1537791 
DeLozier, S. J., \& Rhodes, M. G. (2017). Flipped classrooms: A review of key ideas and recommendations for practice. Educational Psychology Review, 29(1), 141-151. https://doi.org/10.1007/ s10648-015-9356-9

Dichev, C., \& Dicheva, D. (2017). Gamifying education: what is known, what is believed and what remains uncertain: a critical review. International Journal of Educational Technology in Higher Education, 14(1), 9. https://doi.org/10.1186/s41239-017-0042-5

Dilley, A., Kaufman, J., Kennedy, C., \& Plucker, J. (2015). What we know about Critical Thinking? Partnership for 21st Century Learning. https://tinyurl.com/y74mkhf5

Ding, L. (2019). Applying gamifications to asynchronous online discussions: A mixed methods study. Computers in Human Behavior, 91, 1-11. https://doi.org/10.1016/j.chb.2018.09.022

Ekici, M. (2021). A systematic review of the use of gamification in flipped learning. Education and Information Technologies, 26, 3327-3346. https://doi.org/10.1007/s10639-020-10394-y

English, L. D. (2017). Advancing elementary and middle school STEM education. International Journal of Science and Mathematics Education, 15(S1), 5-24. https://doi.org/10.1007/ s10763-017-9802-x

Eppard, J., \& Rochdi, A. (2017). A framework for flipped learning. International Association for Development of the Information Society (IADIS) International Conference on Mobile Learning (13th, Budapest, Hungary, Apr 10 - 12, 2017). https://tinyurl.com/5m7mb4ma

Fukuda, M., Hung-Hsuan, H., Kuwabara, K., \& Nishida, T. (2018). Proposal of a multi-purpose and modular virtual classroom framework for teacher training. Proceedings of the 18th International Conference on Intelligent Virtual Agents (pp. 355 - 356). doi: 10.1145/3267851.3267917

Gedera, D. (2014). Students' experiences of learning in a virtual classroom: An Activity Theory perspective. International Journal of Education and Development Using ICT, 10(4), 93 - 101. https://tinyurl.com/5cafsz5b

Gess, A.H. (2017). STEAM education: Separating fact from fiction. Technology and Engineering Teacher, 77(3), 39 - 41. https://eric.ed.gov/?id=EJ1158969

Guilford. (1991). Psychometric Methods. McGraw-Hill.

Hakak, S., Noor, N. F. M., Ayub, M. N., Affal, H., Hussin, N., Ahmed, E., \& Imran, M. (2019). Cloud-assisted gamification for education and learning - Recent advances and challenges. Computers \& Electrical Engineering, 74, 22-34. https://doi.org/10.1016/j.compeleceng.2019.01.002

Hakulinen, L., \& Auvinen, T. (2014). The effect of gamification on students with different achievement goal orientations. In 2014 International Conference on Teaching and Learning in Computing and Engineering (LaTiCE), 9-16. doi: 10.1109/latice.2014.10

Hamari, J., \& Koivisto, J. (2015). Why do people use gamification services? International Journal of Information Management, 35(4), 419-431. https://doi.org/10.1016/j.ijinfomgt.2015.04.006

Hassan, L., Dias, A., \& Hamari, J. (2019). How motivational feedback increases user's benefits and continued use: A study on gamification, quantified-self and social networking. International Journal of Information Management, 46, 151-162. https://doi.org/10.1016/j.ijinfomgt.2018.12. 004

Henriksen, D. (2014). Full STEAM ahead: creativity in excellent STEM teaching practices. STEAM, 1(2), 1-9. https://doi.org/10.5642/steam.20140102.15

Holm-Hadulla, R. M. (2010). Creativity: concept and lifestyle. Vandenhoeck \& Ruprecht.

Hou, X., Lu, Y., \& Dey, S. (2017). A novel hyper-cast approach to enable cloud-based virtual classroom applications. IEEE International Symposium on Multimedia (ISM), 2016, 533-536. https://doi.org/ 10.1109/ISM.2016.0117

How, M.-L., \& Hung, W. L. D. (2019). Educing AI-Thinking in Science, Technology, Engineering, Arts, and Mathematics (STEAM). Education. Education Sciences, 9(3), Article 184. https://doi.org/10. 3390/educsci9030184

Hsiao, P.-W., \& Su, C.-H. (2021). A study on the impact of STEAM education for sustainable development courses and its effects on student motivation and learning. Sustainability, 13(7), Article 3772. https://doi.org/10.3390/su13073772

Hsu, C.-L., Chen, Y.-C., Yang, T.-N., \& Lin, W.-K. (2017). Do website features matter in an online gamification context? Focusing on the mediating roles of user experience and attitude. Telematics and Informatics, 34(4), 196-205. https://doi.org/10.1016/j.tele.2017.01.009

Hursen, C., \& Bas, C. (2019). Use of gamification applications in science education. International Journal of Emerging Technologies in Learning, 14(1), 4-23. https://doi.org/10.3991/ijet.v14i01.8894

Illeris, K. (2002). The three dimensions of learning: contemporary learning theory in the tension field between the cognitive, the emotional and the social. Roskilde University Press. 
Jantakoon, T., Wannapiroon, P., \& Nilsook, P. (2019). Virtual immersivelearning environments (VILEs) based on digital storytelling to enhance deeper learning for undergraduate students. Higher Education Studies, 9(1), 144-150. https://doi.org/10.5539/hes.v9n1p144

Jia, Y., Xu, B., Karanam, Y., Voida, S. (2016). Personality-targeted gamification: a survey study on personality traits and motivational affordances. Proceedings of the $2016 \mathrm{CHI}$ Conference on Human Factors in Computing Systems - CHI '16. doi: https://doi.org/10.1145/2858036.2858515

Joia, L. A., \& Lorenzo, M. (2021). Zoom in, Zoom out: The impact of the COVID-19 pandemic in the classroom. Sustainability, 13(5), Article 2531. https://doi.org/10.3390/su13052531

Kadambaevna, R. K., Bekchanqizi, S., Muminboevna, R. L., Navfalqizi, D. Z., Amatchonovna, A. S., \& Erkinovna, F. G. (2021). Implementing blended learning technology. Elementary Education Online, 20(4), 443 - 446. https://www.ilkogretim-online.org/?mno=54563

Kankaew, V., \& Wannapiroon, P. (2019). System architecture for virtual team campus on cloud to support internal quality assurance of Rajamangala University of Technology. International Journal of Online and Biomedical Engineering, 15(07), 99-110. https://doi.org/10.3991/ijoe.v15i07.10414

Koivisto, J., \& Hamari, J. (2019). The rise of motivational information systems: A review of gamification research. International Journal of Information Management, 45, 191-210. https://doi.org/10. 1016/j.ijinfomgt.2018.10.013

Krause, M., Mogalle, M., Pohl, H., \& Williams, J. J. (2015). A playful game changer: Fostering student retention in online education with social gamification. ACM Conference on Learning@ Scale, (pp. 95-102). https://dl.acm.org/citation.cfm?id=2724665

Laisema, S., \& Wannapiroon, P. (2014). Design of collaborative learning with creative problem-solving process learning activities in a ubiquitous learning environment to develop creative thinking skills. Procedia - Social and Behavioral Sciences, 116, 3921-3926. https://doi.org/10.1016/j.sbspro.2014. 01.867

Lawrence, S., Giles, C. L., \& Bollacker, K. (1999). Digital libraries and autonomous citation indexing. Computer, 32(6), 67 - 71. doi: 10.1109/2.769447

Li, Q., Li, Z., \& Han, J. (2021). A hybrid learning pedagogy for surmounting the challenges of the COVID-19 pandemic in the performing arts education. Education and Information Technologies, 26, 7635-7655. https://doi.org/10.1007/s10639-021-10612-1

Liao, C. (2016). From interdisciplinary to transdisciplinary: An arts-integrated approach to STEAM education. Art Education, 69(6), 44-49. https://doi.org/10.1080/00043125.2016.1224873

Liao, C., Motter, J. L., \& Patton, R. M. (2016). Tech-savvy girls: learning 21st-century skills through STEAM digital artmaking. Art Education, 69(4), 29-35. https://doi.org/10.1080/00043125.2016. 1176492

Lynch, M. (2019, October 8). Using the arts to develop children's critical thinking skills. The Advocate https://tinyurl.com/jwakzext

Moto, A., Ratanaolarn,T., Tuntiwongwanich, S., \& Pimdee, P. (2018). A Thai junior high school students' 21st Century information literacy, media literacy, and ICT literacy skills factor analysis. International Journal of Emerging Technologies in Learning, 13(9), 87 - 106. doi: https://doi.org/10. 3991/ijet.v13i09.8355

Miller, J., \& Knezek, G. (2013). STEAM for student engagement. Proceedings of the SITE 2013-Society for Information Technology \& Teacher Education International Conference, New Orleans, LA, 25-29 March 2013. pp. 3288-3298. https://tinyurl.com/9d2eprt2

Morrison, J. (2006). Attributes of STEM education: The student, the school, the classroom [Monograph]. Baltimore, MD: Teaching Institute for Excellence in STEM. https://tinyurl.com/9vs3b8tc

National Association of Colleges and Employers. (2016, Sep. 28). Class of 2016 believes it is "Career Ready," but is it? http://tinyurl.com/ya8a559g

National Council for Excellence in Critical Thinking (2017). A draft statement of principles. https://tinyurl.com/y79xcx52

Nielson, B. (2017, April 24). Gamification mechanics vs. gamification dynamics. https://tinyurl.com/ $322 \mathrm{mjt} 7 \mathrm{~m}$

Nitko, A.J. (2004). Educational Assessment of Students (4th ed.), Pearson Education, Inc.

Nyumba, T. O., Wilson, K., Derrick, C. J., \& Mukherjee, N. (2018). The use of focus group discussion methodology: Insights from two decades of application in conservation. Methods in Ecology and Evolution, 9, 20-32. https://doi.org/10.1111/2041-210X.12860

OECD and Eurostat (2005) Oslo manual: Guidelines for collecting and interpreting innovation data $\left(3^{\mathrm{rd}}\right.$ ed.). https://ec.europa.eu/eurostat/documents/3859598/5889925/OSLO-EN.PDF 
Ogunleye, J. (2018). Creativity and innovation in STEM Education. In F. K. Reisman (Ed.), Creatvity and Innovaton in STEM Educaton (pp. 12 - 13). https://tinyurl.com/4ce4af7xOrnstein, A. C., \& Levine, D. U. (2006). Foundations of Education (8th ed.). Houghton Mifflin.

Ortiz, M., Chiluiza, K., \& Valcke, M. (2016). Gamification in higher education and STEM: A Systematic review of the literature. EDULEARN16 Proceedings. doi: 10.21125/edulearn.2016.0422

Özer, H. H., Kanbul, S., \& Ozdamli, F. (2018). Effects of the gamification supported flipped classroom model on the attitudes and opinions regarding game-coding education. International Journal of Emerging Technologies in Learning, 13(1), 109-123.

Parmin, P., Saregar, A., Deta, U. A., \& El Islami, R. A. Z. (2020). Indonesian science teachers' views on attitude, knowledge, and application of STEM. Journal for the Education of Gifted Young Scientists, 8(1), 17-31. https://doi.org/10.17478/jegys.647070

Patterson, A., \& Muna, N. (2019). 3-D printing as a STEAM tool for bridging artistic and technical design perspectives. Steam, 4(1), 1-2. https://doi.org/10.5642/steam.20190401.10

Perignat, E., \& Katz-Buonincontro, J. (2019). STEAM in practice and research: An integrative literature review. Thinking Skills and Creativity, 31, 31-43. https://doi.org/10.1016/j.tsc.2018.10.002

Phuapan, P., Viriyavejakul, C., \& Pimdee, P. (2016). An analysis of digital literacy skills among Thai university seniors. International Journal of Emerging Technologies in Learning, 11(03), 24-31. https://doi.org/10.3991/ijet.v11i03.5301

Pimdee, P. (2020). Antecedents of Thai student teacher sustainable consumption behavior. Heliyon, 6(8), e04676. https://doi.org/10.1016/j.heliyon.2020.e04676

Rahmawati, Y., Ridwan, A., Hadinugrahaningsih, T., \& Soeprijanto. (2019). Developing critical and creative thinking skills through STEAM integration in chemistry learning. Journal of Physics: Conference Series, 1156(1). https://doi.org/10.1088/1742-6596/1156/1/012033

Rajaram, K. (2021). Engaging Learners: A flipped classroom approach. In Evidence-Based Teaching for the 21st Century Classroom and Beyond. Springer. https://doi.org/10.1007/978-981-33-6804-0_2

Riegel, C., \& Kozen, A. (2016). Attaining 21st Century skills in a virtual classroom educational planning, 23(3), 41 - 55. https://tinyurl.com/cwb7u9t4

Rodrigues, L. F., Oliveira, A., \& Rodrigues, H. (2019). Main gamification concepts: A systematic mapping study. Heliyon, 5(7), e01993. https://doi.org/10.1016/j.heliyon.2019.e01993

Ruangvanich, S., \& Nilsook, P. (2018). Personality learning analytics system in intelligent virtual learning environment. ACM International Conference Proceeding Series, 245 - 250. doi: $10.1145 / 3301551.3301582$

Ruenphongphun, P., Sukkamart, A., \& Pimdee, P. (2021). Thai undergraduate digital citizenship skills: A second-order confirmatory factor analysis (CFA). World Journal on Educational Technology: Current Issues, 13(3), 370-385. https://doi.org/10.18844/wjet.v13i3.5937

Rujivanarom, P. (2016, December 14). School system's failure to teach logical thinking linked to low PISA scores. The Nation. http://tinyurl.com/l68ugux.

Sanchez, D. R., Langer, M., \& Kaur, R. (2019). Gamification in the classroom: Examining the impact of gamified quizzes on student learning. Computers \& Education, 144, Article 103666. https://doi. org/10.1016/j.compedu.2019.103666

Sanders, M. (2009). STEM, STEM education, STEMmania. The Technology Teacher, 68(4), 20-26.

Santosa, E. B., Degeng, I. N. S., Sulton, \& Kuswandi, D. (2020). The effects of mobile computer-supported collaborative learning to improve problem solving and achievements. Journal for the Education of Gifted Young Scientists, 8(1), 325 - 342. https://tinyurl.com/474kp8nz

Sarnok, K., Wannapiroon, P., \& Nilsook, P. (2019). Digital learning ecosystem by using digital storytelling for teacher profession students. International Journal of Information and Education Technology, 9(1), 21-26. https://doi.org/10.18178/ijiet.2019.9.1.1167

Sayavaranont, P., \& Piriyasurawong, P. (2019). Virtual community of practice using human performance technology to enhance innovation competency and innovation for high performance organization. TEM Journal, 8(4), 1461 - 1468. ttps://doi.org/10.18421/TEM84-51

Shih, W.-L., \& Tsai, C.-Y. (2017). Students' perception of a flipped classroom approach to facilitating online project-based learning in marketing research courses. Australasian Journal of Educational Technology, 33(5). https://doi.org/10.14742/ajet.2884

Smiderle, R., Rigo, S. J., Marques, L. B., et al. (2020). The impact of gamification on students' learning, engagement and behavior based on their personality traits. Smart Learn. Environ, 7(3). https://doi. org/10.1186/s40561-019-0098-x

Smith, D. (2006). Exploring Innovation. McGraw-Hill. 
Songkram, N. (2017). Virtual smart classroom to enhance 21st century skills in learning and innovation for higher education learners. Proceedings of the 2017 Tenth International Conference on Mobile Computing and Ubiquitous Network (ICMU). doi: 10.23919/icmu.2017.8330109

Sosa, M. E. (2011). Where do creative interactions come from? The role of tie content and social networks. Organization Science, 22(1), 1-21. https://doi.org/10.1287/orsc.1090.0519

Srikan, P., Pimdee, P., Leekitchwatana, P., \& Narabin, A. (2021). A Problem-Based Learning (PBL) and Teaching Model using a Cloud-Based Constructivist Learning Environment to Enhance Thai Undergraduate Creative Thinking and Digital Media Skills. International Journal of Interactive Mobile Technologies, 15(22), 68. https://doi.org/10.3991/ijim.v15i22.24963

Taylor, P. C. (2016). Evaluating the benefit of the maker movement in K-12 STEM education. Electronic International Journal of Education, Arts, and Science, 2, 1 - 22. https://tinyurl.com/anksn527

Techakosit, S., \& Wannapiroon, P. (2015). Connectivism learning environment in augmented reality science laboratory to enhance scientific literacy. Procedia - Social and Behavioral Sciences, 174(2), 2108-2115. https://doi.org/10.1016/j.sbspro.2015.02.009

Thayer-Bacon, B. J. (1998). Transforming and redescribing critical thinking: Constructive thinking. Studies in Philosophy and Education, 17(2). https://doi.org/10.1023/A:1005166416808

Thuneberg, H. M., Salmi, H. S., \& Bogner, F. X. (2018). How creativity, autonomy and visual reasoning contribute to cognitive learning in a STEAM hands-on inquiry-based math module. Thinking Skills and Creativity, 29(July), 153-160. https://doi.org/10.1016/j.tsc.2018.07.003

Toda, A. M., do Carmo, R. M. C., da Silva, A. P., Bittencourt, I. I., \& Isotani, S. (2019). An approach for planning and deploying gamification concepts with social networks within educational contexts. International Journal of Information Management, 46, 294 - 303. doi: 10.1016/j. ijinfomgt.2018.10.001

Tremblay, K., Lalancette, D., \& Roseveare, D. (2012). Assessement of higher education learning outcomes (AHELO): Feasibility study report-Volume 1-Design and implementation. OECD. https:// tinyurl.com/2ud9uza2

Ugras, M. (2018). The effects of STEM activities on STEM attitudes, scientific creativity and motivation beliefs of the students and their views on STEM education. International Online Journal of Educational Sciences, 10(5), 165-182. https://doi.org/10.15345/iojes.2018.05.012

Wahono, B., Lin, P. L., \& Chang, C. Y. (2020). Evidence of STEM enactment effectiveness in Asian student learning outcomes. International Journal of STEM Education, 7(36), 1-18. https://doi.org/10. 1186/s40594-020-00236-1

Wai, J., Lubinski, D., Benbow, C. P., \& Steiger, J. H. (2010). Accomplishment in science, technology, engineering, and mathematics (STEM) and its relation to STEM educational dose: A 25-year longitudinal study. Journal of Educational Psychology, 102(4), 860-871. https://doi.org/10.1037/ a0019454

Wannapiroon, N., \& Petsangsri, S. (2020). Effects of STEAMification Model in flipped classroom learning environment on creative thinking and creative innovation. TEM Journal, 9(4), 1647 - 1655 doi: 10.18421/TEM94-42.

Werbach, K., \& Hunter, D. (2015). The gamification toolkit: Dynamics, mechanics, and components for the win. Wharton School Press. https://tinyurl.com/26hvpfvm

Weyrauch, T., \& Herstatt, C. (2016). What is frugal innovation? Three defining criteria. Journal of Frugal Innovation, 2, 1. https://doi.org/10.1186/s40669-016-0005-y

White, D. W. (2014). 'What Is STEM education and why is it important? Florida Association of Teacher Educators Journal, 1(14), 1 - 9. http://www.fate1.org/journals/2014/white.pdf

Yuktirat, C., Sindhuphak, A., \& Kiddee, K. (2018). M-learning for the art of drawing: Informal learning for a digital age. International Journal of Interactive Mobile Technologies, 12(5), 152 - 168. doi: 10.3991/ijim.v12i5.9207

Publisher's note Springer Nature remains neutral with regard to jurisdictional claims in published maps and institutional affiliations. 


\section{Authors and Affiliations}

\section{Naphong Wannapiroon ${ }^{1}\left[\right.$. Paitoon Pimdee ${ }^{1}$}

$\triangle$ Paitoon Pimdee

paitoon.pi@kmitl.ac.th

Naphong Wannapiroon

naphong.w@rmutsb.ac.th

1 Department of Industrial Education, School of Industrial Education and Technology, King Mongkut's Institute of Technology Ladkrabang (KMITL), 1 Chalong Krung 1 Alley, Lat Krabang, Bangkok 10520, Thailand 